\title{
Southward migration of continental volcanic activity in the Sierra de Las Cruces, Mexico: palaeomagnetic and radiometric evidence
}

\author{
María Luisa Osete ${ }^{\text {a, * }}$, Vicente-Carlos Ruiz-Martínez ${ }^{\text {a }}$, Cecilia Caballero ${ }^{\text {b }}$, \\ Carmen Galindo ${ }^{c}$, Jaime Urrutia-Fucugauchi ${ }^{\mathrm{b}}$, Donald H. Tarling ${ }^{\mathrm{d}}$ \\ a Departamento de Física de la Tierra, Facultad de Ciencias Físicas, Universidad Complutense de Madrid, 28040 Madrid, Spain \\ ${ }^{\mathrm{b}}$ Laboratorio de Paleomagnetismo y Geofísica Nuclear, Instituto de Geofísica. Universidad Nacional Autónoma de México, \\ Mexico D.F. 04510, Mexico

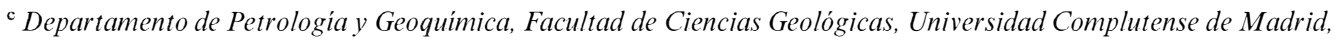 \\ 28040 Madrid, Spain \\ ${ }^{\mathrm{d}}$ Department of Geological Sciences, University of Plymouth, Plymouth PL4 8AA, UK
}

\begin{abstract}
New Palaeomagnetic data for 30 sites (271 samples) and K-Ar data from five units in the Sierra de Las Cruces, western Basin of Mexico, provide constraints on the spatial-temporal evolution of arc magmatism in the central Trans-Mexican Volcanic Belt. The normal and reversed directions show a polarity pattern with a consistent spatial zonation perpendicular to the NNW-SSE trend of the range. The magnetostratigraphy and $\mathrm{K}-\mathrm{Ar}$ dates indicate that volcanic activity in the Sierra de Las Cruces migrated southeastward at a mean rate of $1.6 \mathrm{~cm} / \mathrm{a}$, between 3.6 and $1.8 \mathrm{Ma}$, and that the rate of migration may have been higher, up to $4 \mathrm{~cm} / \mathrm{a}$, during the Gauss Chron. Normal and reversed directions pass the reversal test at a 95\% confidence level. The mean Plio-Quaternary palaeomagnetic direction for Sierra de Las Cruces is $D=350.7^{\circ}, I=30.6^{\circ}\left(N=25, k=30.7, \alpha_{95}=5.3^{\circ}\right)$. The declination deviates to the west of the expected direction, which suggests that small counterclockwise rotations could take place during formation of the Sierra de Las Cruces volcanics.
\end{abstract}

Keywords: continental volcanism; K-Ar dating; palaeomagnetism; Trans-Mexican Volcanic Belt; volcanic activity migration

\section{Introduction}

The Trans-Mexican Volcanic Belt (TMVB) is an E-W-elongated structure that crosses central Mexico from the Pacific Ocean to the Gulf of Mexico between the 19th and 21st parallels (Fig. la inset). The TMVB is superimposed on the

\footnotetext{
* Corresponding author. Fax: + 34-91-3944-398.

E-mail address: mlosete@eucmax.sim.ucm.es (M.L. Osete)
}

NNW-SSE structural grain of Mexico, crossing Oligocene-Miocene ignimbrites and associated rocks of Sierra Madre Occidental, the Mesozoic fold belt of the Sierra Madre Oriental, overthrust terranes of the Cordillera and Palaeozoic basement rocks. On the basis of geochronological, petrological and structural data, the TMVB is often divided into three sectors: the western sector from the Pacific coast to the Colima graben, the central sector extending from the Michoacan volcanic zone towards either the Valley of Mexico and 

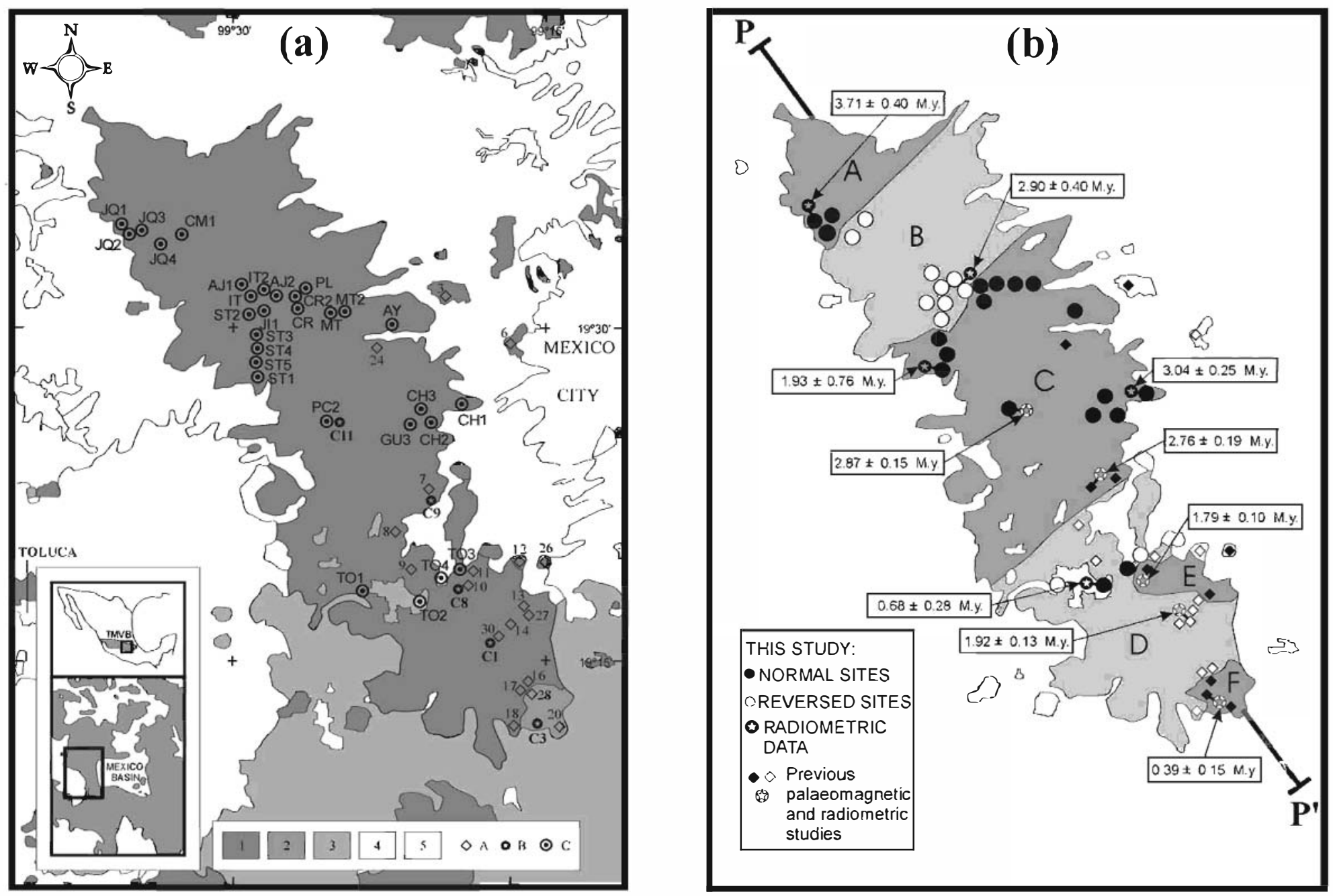

Fig. 1. (A) Geological sketch of Sierra de Las Cruces (simplified from Mooser et al., 1974; INEGI, 1986; Mora-Alvarez et al., 1991), showing sampling sites and previous sites with radiometric and palaeomagnetic information. $1=$ Tertiary volcanism, $2=$ Ajusco volcanic complex, $3=$ Quaternary volcanics of the Chichinautzin group, $4=$ undiferentiated lahar and Tertiary sediments, $5=$ alluvium and lake deposits. $\mathrm{A}=$ sites of previous palaeomagnetic studies referred in Table 2 , $\mathrm{B}=$ location of previous sites radiometrically investigated referred in Table 1. C=sites palaeomagnetically investigated in this study. (b) Simplified map of Sierra de Las Cruces showing the magnetic zonation proposed and the available geochronologic results. $P-P^{\prime}=$ considered trend of the Sierra de Las Cruces Range. 
Sierra Nevada (Nixon et al., 1987) or towards the Queretaro-Taxco lineament (Pasquarè et al., 1991), and the eastern segment from Sierra Nevada, or the Queretaro-Taxco lineament, eastwards towards the Gulf of Mexico. The chemical and petrological characteristics indicate that the TMVB volcanic sequences are generally calc-alkaline, although some localized zones of alkaline volcanism occur, particularly in the western sector (e.g. Luhr et al., 1985; Nixon et al., 1987). In addition, young volcanism is represented by the eastern alkaline province of Oligocene to Quaternary age (Cantagrel and Robin, 1979). There are three fundamental characteristics of the TMVB that are controversial: its orientation relative to the Middle America Trench, the time of onset of arc volcanism, and whether there has been systematic spatial-temporal migration of volcanic activity:

(1) One of the most striking structural features of the TMVB is its oblique $\left(\approx 16^{\circ}\right)$ orientation relative to the Middle American Trench. This geometry has given rise to several contrasting models to explain this non-parallelism and to relate the volcanism with the northeasterly subduction of oceanic lithosphere beneath the southern Mexican continental margin (Molnar and Sykes, 1969; Urrutia-Fucugauchi and Del Castillo, 1977; Demant, 1978; Nixon, 1982; Pardo and Suarez 1995 and others). Other models consider that the TMVB has no direct tectonic relation with the subduction along the Middle American Trench, being a consequence of zones of weakness within the crust in this area, which have been inherited from earlier episodes of deformation (e.g. Mooser, 1972; Shurbert and Cebull, 1973). On the basis of seismic information, Pardo and Suarez (1995) suggested that the non-parallelism is due to the changing geometry of the Rivera and Cocos plates beneath southern Mexico.

(2) Earlier studies suggested that the onset of volcanic activity in the TMVB was in the Quaternary (Demant, 1978), the Late Pliocene (Cantagrel and Robin, 1979), the Early Pliocene (Nixon et al., 1987) or Late Oligocene (Mooser, 1972). Ferrari et al. (1994) reviewed these alternatives together with chronologic, stratigraphic and structural data, and concluded that the TMVB began at about $16 \mathrm{Ma}$ and that its tectonic evolution comprised a Middle Miocene phase of transcurrent faulting followed by a transtensional to extensional phase between the Late Miocene and present. In this model, the NW-SE and E-W transcurrent faults provided preferential conduits for crustal magma, resulting in an oblique orientation with respect to the trench. The early stages of TMVB activity have been recently traced to widespread mafic to intermediate volcanism, between about 11 and $7 \mathrm{Ma}$ (Ferrari et al., 2000 - this volume). This volcanism has been documented in western and central Mexico, where it is characterized by plateau sequences, shield volcanoes, fissural lava flows and monogenetic cinder cones (e.g. Ferrari et al., 1994, 2000 - this volume; Moore et al., 1994; Rosas-Elguera et al., 1997).

(3) An apparent spatial north-south migration of volcanic activity in the TMVB has been pointed out in several studies (e.g. Cantagrel and Robin, 1979; Nixon et al., 1987; Mora-Alvarez et al., 1991; Delgado-Granados et al., 1995). However, this general trend has only been investigated in detail in the Michoacan-Guanajuato and Chapala regions (Ban et al., 1992; Delgado-Granados et al., 1995). Preliminary radiometric studies (MoraAlvarez et al., 1991) in the central and southern part of the Sierra de Las Cruces, within the Mexico Basin, have also indicated an apparent southward migration of volcanic activity.

In this paper, the suggested southward migration in the Sierra de Las Cruces region is considered further in the light of new geochronological information and detailed palaeomagnetic investigations. This study was also intended as a pilot study to establish a magnetoestratigraphy that can be applied to the TMVB and to assess the best criteria for selecting future sites for further radiometric and palaeomagnetic study. The palaeomagnetic aspects were mainly concerned with evaluating the extent to which block rotations have played an important role in the structural evolution of the TMVB, as proposed by UrrutiaFucugauchi and Böhnel (1988). The palaeomagnetic sampling sites were mostly concentrated in the central and northern part of the Sierra de Las Cruces. A total of 329 cores ( 481 specimens) from 30 sites were obtained, and 271 samples were 
analyzed in the laboratory. After consideration of the palaeomagnetic results, five of the sites were selected for $\mathrm{K}-\mathrm{Ar}$ dating.

\section{Geologic setting and sampling}

The Sierra de Las Cruces is formed by a series of volcanic structures and associated lava flows, pyroclastic and lahar products, distributed along a NNW-SSE range in the central part of the TMVB (Fig. 1a). This range marks the western margin of the Basin of Mexico and separates it from the Valley of Toluca. A formal stratigraphy of this area was first provided by Fries (1960) and Schlaepfer (1968). Three formations can be distinguished from North to South: Las Cruces Formation, the El Ajusco Formation and the Chichinautzin Group. Towards the south, Las Cruces Formation underlies the Ajusco Formation and is covered by the pyroclasts and lavas of the Chichinautzin Group. A detailed volcanic stratigraphy for the Basin of Mexico has been difficult to establish, mainly because of the lack of radiometric dates and field studies. Mooser et al. (1974) considered that the main mass of Sierra de Las Cruces was formed by consecutive episodes of faulting accompanied by the formation of stratovolcanoes that were pro- gressively displaced southwards. They also considered that the volcanism had been fairly continuous and extended back into the Late Miocene. Geochemical studies of the Basin of Mexico volcanics have been reported by Gunn and Mooser (1971) and Richter and Negendank (1976). The volcanic units show calc-alkaline afinities, being formed by andesites, dacites and, to a minor exent, by basalts. Lugo-Hubp (1984), from geomorphological studies, concluded that the more eroded volcanoes are in the northern sector of the range. Recently, Delgado-Granados and Martín del Pozo (1993), as part of a geological study of Mexico City's southern volcanic area, identified three different eruptive episodes that occurred from Late Pliocene to Holocene at the junction between the Las Cruces, Ajusco and Chichinautzin ranges (SW Mexico Basin). They considered that the oldest eruptive period, the Las Cruces Formation, was formed mostly during Late Pliocene-Early Pleistocene times. During the Ajusco eruptive period, in the Middle Pleistocene, the Ajusco volcano was formed by extrusion of several andesitic lava domes. The last stage was identified as the Chichinautzin eruptive period of monogenetic volcanism, characterized by Strombolian-type activity during the Late Pleistocene-Holocene. No detailed volcano-stratigraphic studies have yet been carried out in the

Table 1

Summary of radiometric data from Sierra de Las Cruces

\begin{tabular}{|c|c|c|c|c|c|c|c|}
\hline Site & $\begin{array}{l}\text { Latitude } \\
(\mathrm{N})\end{array}$ & $\begin{array}{l}\text { Longitude } \\
\text { (W) }\end{array}$ & Rock type & $\begin{array}{l}\text { Percentage } \\
\mathrm{K}\end{array}$ & $\begin{array}{l}\text { Percentage } \\
{ }^{40} \mathrm{Ar}_{\mathrm{atm}}(\%)\end{array}$ & $\begin{array}{l}\text { Percentage } \\
{ }^{40} \mathrm{Ar}_{\mathrm{rag}}(\mu \mathrm{l} / \mathrm{g})\end{array}$ & $\begin{array}{l}\text { Age }(\mathrm{Ma}) \\
( \pm 2 \sigma)\end{array}$ \\
\hline \multicolumn{8}{|c|}{ This study } \\
\hline $\mathrm{JQ}^{\mathrm{a}}$ & $19^{\circ} 33^{\prime} 48^{\prime \prime}$ & $99^{\circ} 34^{\prime} 50^{\prime \prime}$ & Andesite & 1.89 & 86.99 & 0.2728 & $3.71 \pm 0.40$ \\
\hline $\mathrm{AJ} 2^{\mathrm{b}}$ & $19^{\circ} 31^{\prime} 20^{\prime \prime}$ & $99^{\circ} 28^{\prime} 05^{\prime \prime}$ & Andesite & 0.78 & 87.29 & 0.0868 & $2.90 \pm 0.40$ \\
\hline $\mathrm{CH}^{\mathrm{a}}$ & $19^{\circ} 26^{\prime} 15^{\prime \prime}$ & $99^{\circ} 19^{\prime} 20^{\prime \prime}$ & Basalt & 1.58 & 81.37 & 0.1868 & $3.04 \pm 0.25$ \\
\hline $\mathrm{ST} 1^{\mathrm{a}}$ & $19^{\circ} 28^{\prime} 08^{\prime \prime}$ & $99^{\circ} 28^{\prime} 49^{\prime \prime}$ & Dacite & 1.73 & 96.43 & 0.1298 & $1.93 \pm 0.76$ \\
\hline $\mathrm{TO}^{\mathrm{a}}$ & $19^{\circ} 17^{\prime} 40^{\prime \prime}$ & $99^{\circ} 20^{\prime} 27^{\prime \prime}$ & Basalt & 1.30 & 96.13 & 0.0343 & $0.68 \pm 0.28$ \\
\hline \multicolumn{8}{|c|}{ Mora-Alvarez et al. (1991) } \\
\hline $\mathrm{C} 11$ & $19^{\circ} 25^{\prime} 40^{\prime \prime}$ & $99^{\circ} 25^{\prime} 29^{\prime \prime}$ & Andesite & 1.42 & 43.4 & 0.1580 & $2.87 \pm 0.15$ \\
\hline $\mathrm{C} 9$ & $19^{\circ} 22^{\prime} 28^{\prime \prime}$ & $99^{\circ} 20^{\prime} 08^{\prime \prime}$ & Andesite & 2.03 & 67.8 & 0.2180 & $2.76 \pm 0.19$ \\
\hline $\mathrm{C} 8$ & $19^{\circ} 18^{\prime} 29^{\prime \prime}$ & $99^{\circ} 19^{\prime} 00^{\prime \prime}$ & Andesite & 1.40 & 36.1 & 0.0973 & $1.79 \pm 0.10$ \\
\hline $\mathrm{Cl}$ & $19^{\circ} 16^{\prime} 00^{\prime \prime}$ & $99^{\circ} 17^{\prime} 15^{\prime \prime}$ & Andesite & 1.63 & 44.76 & 0.1219 & $1.92 \pm 0.13$ \\
\hline $\mathrm{C} 3$ & $19^{\circ} 11^{\prime} 45^{\prime \prime}$ & $99^{\circ} 15^{\prime} 38^{\prime \prime}$ & Basalt & 0.79 & 79.0 & 0.0121 & $0.39 \pm 0.16$ \\
\hline
\end{tabular}

\footnotetext{
${ }^{a}$ Whole-rock dating
}

${ }^{b}$ Plagioclase concentrate dating. 
Table 2

Summary of previous palaeomagnetic data from Sierra de Las Cruces

\begin{tabular}{|c|c|c|c|c|c|c|c|c|}
\hline Sampling site & Dec & Inc & $n / n^{\prime}$ & $\alpha_{95}$ & $k$ & Field & Polarity & Reference \\
\hline C9 Huixquilucan & 340.9 & +16.91 & $2 / 2$ & 9.4 & 708 & NRM & $\mathrm{N}$ & 1 \\
\hline C8 D. los Leones & 70.4 & -20.4 & $25 / 25$ & 3.2 & 82 & NRM & $\mathrm{I}(\mathrm{N})$ & 1 \\
\hline Cl M.Contreras & 144.5 & +18.2 & $23 / 23$ & 11.0 & 9 & NRM & $\mathrm{R}$ & 1 \\
\hline C3-A El Ajusco & 124.1 & +0.4 & $14 / 16$ & 3.8 & 111 & NRM & $\mathrm{I}(\mathrm{R})$ & 1 \\
\hline C3-B El Ajusco & 0.3 & +17.1 & $13 / 14$ & 9.9 & 18 & NRM & $\mathrm{N}$ & 1 \\
\hline 3. Chiluca & 355.2 & +20.6 & $7 / 7$ & 13.5 & 21 & 300 & $\mathrm{~N}$ & 2 \\
\hline 6. Los Remedios & 179.5 & -18.1 & $6 / 7$ & 9.4 & 52 & 77 & $\mathrm{R}$ & 2 \\
\hline 7. Dos Rios & 37.8 & +19.4 & $6 / 6$ & 15.4 & 20 & 300 & $\mathrm{~N}$ & 2 \\
\hline 8. Ignacio Allende & 173.2 & -53.7 & $6 / 6$ & 8.4 & 64 & 300 & $\mathrm{R}$ & 2 \\
\hline 9. La Marquesa & 164.6 & -32.9 & $6 / 7$ & 21.0 & 11 & 300 & $\mathrm{R}$ & 2 \\
\hline 10. Las Cruces & 357.7 & +40.3 & $7 / 7$ & 5.8 & 110 & 150 & $\mathrm{~N}$ & 2 \\
\hline 11. S of La Venta & 174.2 & -61.2 & $7 / 7$ & 4.8 & 157 & NRM & $\mathrm{R}$ & 2 \\
\hline 12. Cerro Judio & 184.0 & -24.1 & $8 / 8$ & 15.6 & 14 & 300 & $\mathrm{R}$ & 2 \\
\hline 13. M. Contreras & 5.1 & +36.1 & $7 / 7$ & 4.8 & 162 & 150 & $\mathrm{~N}$ & 2 \\
\hline 14. M. Contreras & 164.8 & -39.5 & $8 / 8$ & 5.8 & 94 & 150 & $\mathrm{R}$ & 2 \\
\hline 16. Monte Alegre & 194.3 & -41.0 & $6 / 6$ & 6.3 & 113 & 150 & $\mathrm{R}$ & 2 \\
\hline 17. Monte Alegre & 187.8 & -32.5 & $6 / 6$ & 22.4 & 13 & 300 & $\mathrm{R}$ & 2 \\
\hline 18. SW of Ajusco & 148.2 & -64.8 & $8 / 8$ & 8.6 & 42 & 600 & $\mathrm{R}$ & 2 \\
\hline 20. SE of Ajusco & 173.5 & -53.8 & $6 / 7$ & 6.0 & 128 & NRM & $\mathrm{R}$ & 2 \\
\hline 24. C. Apaxco & 354.6 & +31.9 & $7 / 7$ & 5.7 & 114 & 150 & $\mathrm{~N}$ & 2 \\
\hline 26. Zacatepetl & 11.5 & +53.8 & $7 / 7$ & 5.3 & 129 & 300 & $\mathrm{~N}$ & 2 \\
\hline 27. M. Contreras & 192.3 & -46.7 & $6 / 6$ & 6.8 & 98 & 150 & $\mathrm{R}$ & 2 \\
\hline 28. El Ajusco & 9.1 & +10.3 & $7 / 7$ & 5.5 & 120 & 300 & $\mathrm{~N}$ & 2 \\
\hline 30. M. Contreras & 161.8 & -48.0 & $4 / 6$ & 11.9 & 60 & 150 & $\mathrm{R}$ & 2 \\
\hline
\end{tabular}

$n / n^{\prime}$ : number of samples used/total. N: normal polarity. R: reverse polarity. I: intermediate polarity. 1: data from Mora-Alvarez et al. (1991). 2: data by Mooser et al. (1974) after selection of Mora-Alvarez et al. (1991).

central and northern part of the Sierra de Las Cruces. Geochronological investigations are also scarce in this region. Mora-Alvarez et al. (1991) reported $\mathrm{K}-\mathrm{Ar}$ dating and palaeomagnetic results from five sites located in the southern sector of the region, along the trend of the range (Table 1). Delgado-Granados and Martín del Pozo (1993) considered that the oldest four sites investigated by Mora-Alvarez et al. (1991) belong to the Las Cruces Formation, while the youngest basalt probably corresponds to volcanism that was younger than that of the Ajusco Formation. Mooser et al. (1974) reported palaeomagnetic data mostly from the southern sector of the ranges (Table 2). Although only a few samples were partially demagnetized, these showed both normal and reversed magnetizations, indicating that different volcanic episodes were involved in the formation of the volcanic range.

A total of 329 cores from 30 sites (Fig. 1a and b) were drilled in the field with a portable petrolpowered drill and oriented in situ with a magnetic compass (after testing that it was not affected by the remanent magnetization of the outcrop). Most sites correspond to the Las Cruces Formation, except sites $\mathrm{TO} 2$ and $\mathrm{TO} 4$, which probably belong to the Ajusco Formation or Chichinautzin Group. No evidences of tilting affecting the sampled volcanic sites were observed. The lithologies include andesites, dacites and a few clinopyroxene \pm olivine \pm amphibole basalts. Some of the freshest samples were retained for potential radiometric determinations. Petrographic study shows that the andesites consist of subhedral, strongly oxidized brown amphibole (hornblende) and zoned plagioclase phenocrysts within a microcrystalline groundmass of clinopyroxene, orthopyroxene, plagioclase and oxides. Zeolites are also present occasionally in the groundmass and as pseudomorphs after some phenocrysts. The dacites contain phenocrysts 


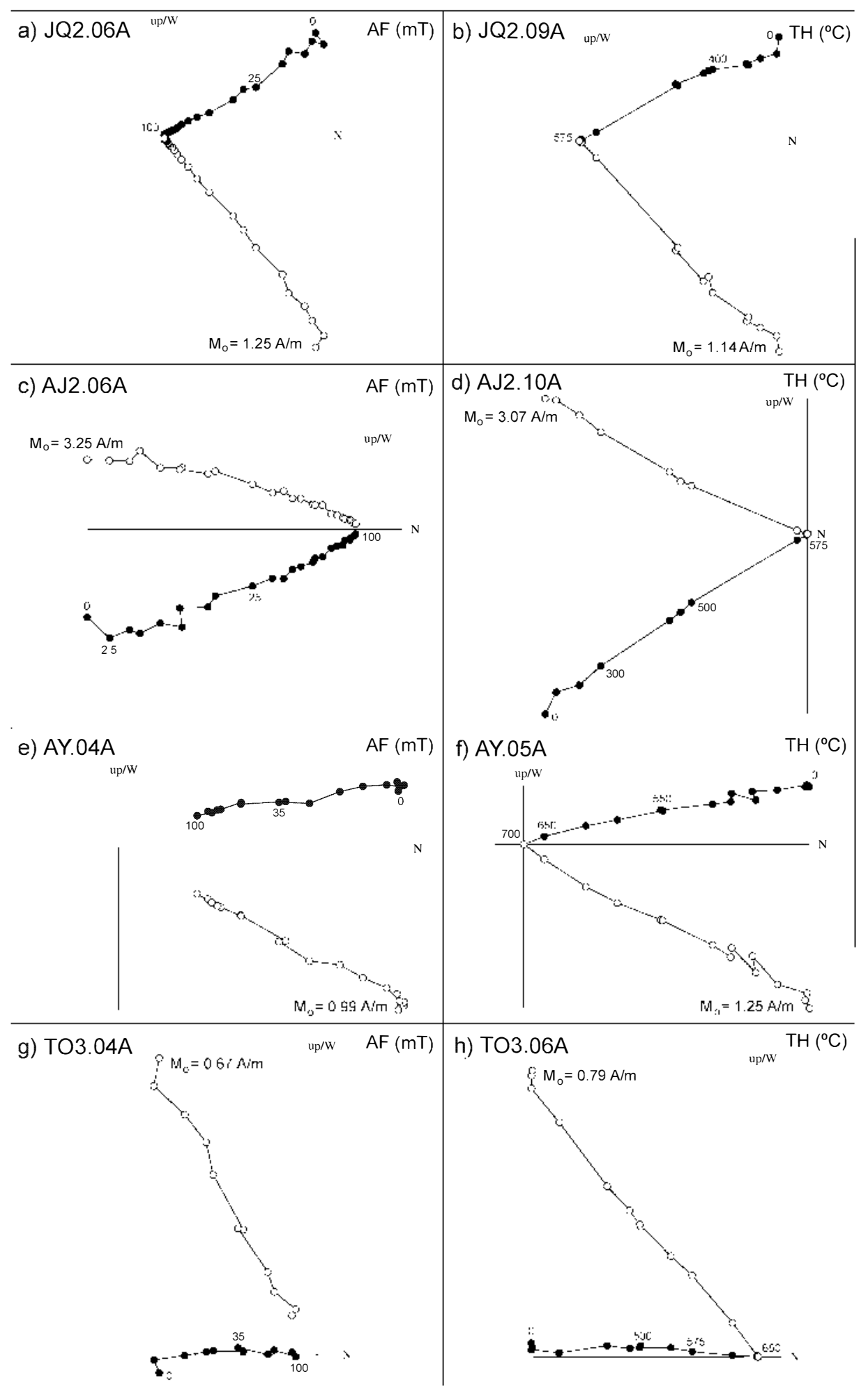


of quartz, amphibole (oxidized hornblende) and two types of plagioclase, consisting, respectively, of subhedral crystals, with oscillatory zoning, and strongly resorbed crystal fragments displaying a discontinuous reverse zonation. These are set in a ground mass similar to that of the andesites. Basalts are scarce in the Sierra de Las Cruces Formation and contain plagioclase, clinopyroxene, oxidized brown amphibole, and sometimes olivine, set in a groundmass of plagioclase and clinopyroxene.

\section{Palaeomagnetic results}

Palaeomagnetic analyses have been carried out in the palaeomagnetic laboratory of the Complutense University of Madrid. The NRM of 481 specimens was measured, and a systematic palaeomagnetic treatment was completed with 271 samples. The natural remanence indicated common within-site directions, with the exception of three sites (JQ4, CM1 and MT which will be described later). The NRM intensities ranged from 0.3 to $18.0 \mathrm{~A} / \mathrm{m}$ and the initial low-field susceptibilities from $1.4 \times 10^{-3}$ to $1.8 \times 10^{-2}$ (SI). At least two samples were selected from each site, for a pilot thermal and AF demagnetization study. Pilot thermal demagnetization was in steps of 25,50 or $100^{\circ} \mathrm{C}$ from room temperature to $700^{\circ} \mathrm{C}$, while $\mathrm{AF}$ was in steps of $2.5 \mathrm{mT}$ up to $20 \mathrm{mT}$, and then in $5 \mathrm{mT}$ steps up to $100 \mathrm{mT}$. After the pilot study, the AF technique was used systematically for the demagnetization of remaining samples. The steps for AF systematic demagnetization were 25, 35, 45, 60, 80 and $100 \mathrm{mT}$. The magnetic behaviour during demagnetization allowed division of the investigated sites into three groups. The first group is characterized by the presence of only one stable component with a maximum unblocking temperature of about $550-575^{\circ} \mathrm{C}$ and median destructive field (MDF) of about 15-25 mT (Figs. 2a-d and
$3 a-d)$. This suggests that the remanence is carried by some fine-grained spinels, most probably by Ti-poor titanomagnetites. Most of the sites belong to the first group. The second group is characterized by one stable component (Fig. 2e-h) that presents higher values of the $\mathrm{MDF}$ and maximum unblocking temperatures over $625^{\circ} \mathrm{C}$ (Fig. 3e-h). Slightly maghemitized Ti-poor titanomagnetite could be the carrier of the magnetization of this second group of samples (Ozdemir, 1990). However, in addition, the presence of two magnetic phases, Ti-poor titanomagnetite and titanohaematite, cannot be excluded.

The three anomalous sites (JQ4, CM1 and MT) belong to the third group, which is characterized by a high scatter of the initial NRM directions, high initial NRM intensity (up to $92 \mathrm{~A} / \mathrm{m}$ ) and the presence of two overlapping directional magnetic components (Fig. 4a and b). The lower coercivity and lower unblocking temperature component shows a high initial intensity and scattered directions. This is interpreted as being due to a secondary IRM induced by lightning strikes. The higher coercivity component is considered to be the characteristic remanent magnetization, ChRM, which is difficult to isolate using principal component analysis (Kirschvink, 1980), because of overlapping the coercivity and thermal spectra with the lightning component. However, a ChRM direction (Fig. 4c) could be calculated using the converging remagnetization circles technique of Halls (1976) and McFadden and McElhinny (1988).

When considering the site mean directions (Table 3), the previous results of Mooser et al. (1974) are excluded because incomplete demagnetization prevented isolation of a ChRM (although these data are included in the polarity assessment). Similarly, the previous five palaeomagnetic directions reported by Mora-Alvarez et al. (1991) were also excluded because only one sample per site was demagnetized (although no apparent second-

Fig. 2. Representative vector demagnetization plots. Solid circles denote the horizontal projection, and open circles denote the vertical projection. First group: (a) normal polarity (AF demagnetization), (b) normal polarity (thermal demagnetization); (c) reversed polarity (AF demagnetization) and (d) reversed polarity (thermal demagnetization). Samples classified as second group: (e) normal polarity (AF demagnetization); (f) normal polarity (thermal demagnetization, (g) reversed polarity (AF) and (h) reversed polarity (Thermal) 

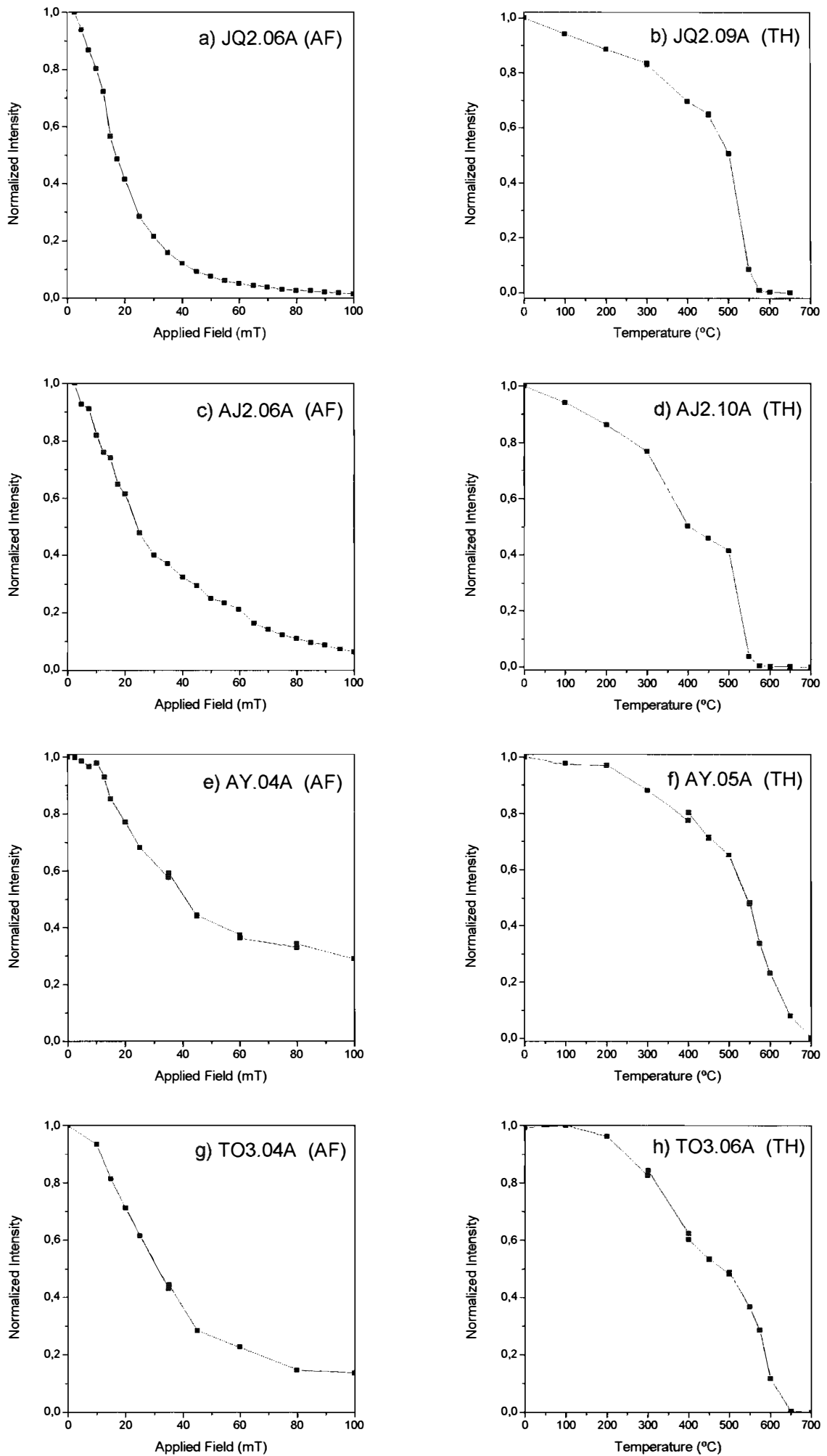

Fig. 3. Normalized intensity versus applied field and/or temperature during demagnetization of samples represented in Fig. 2. 


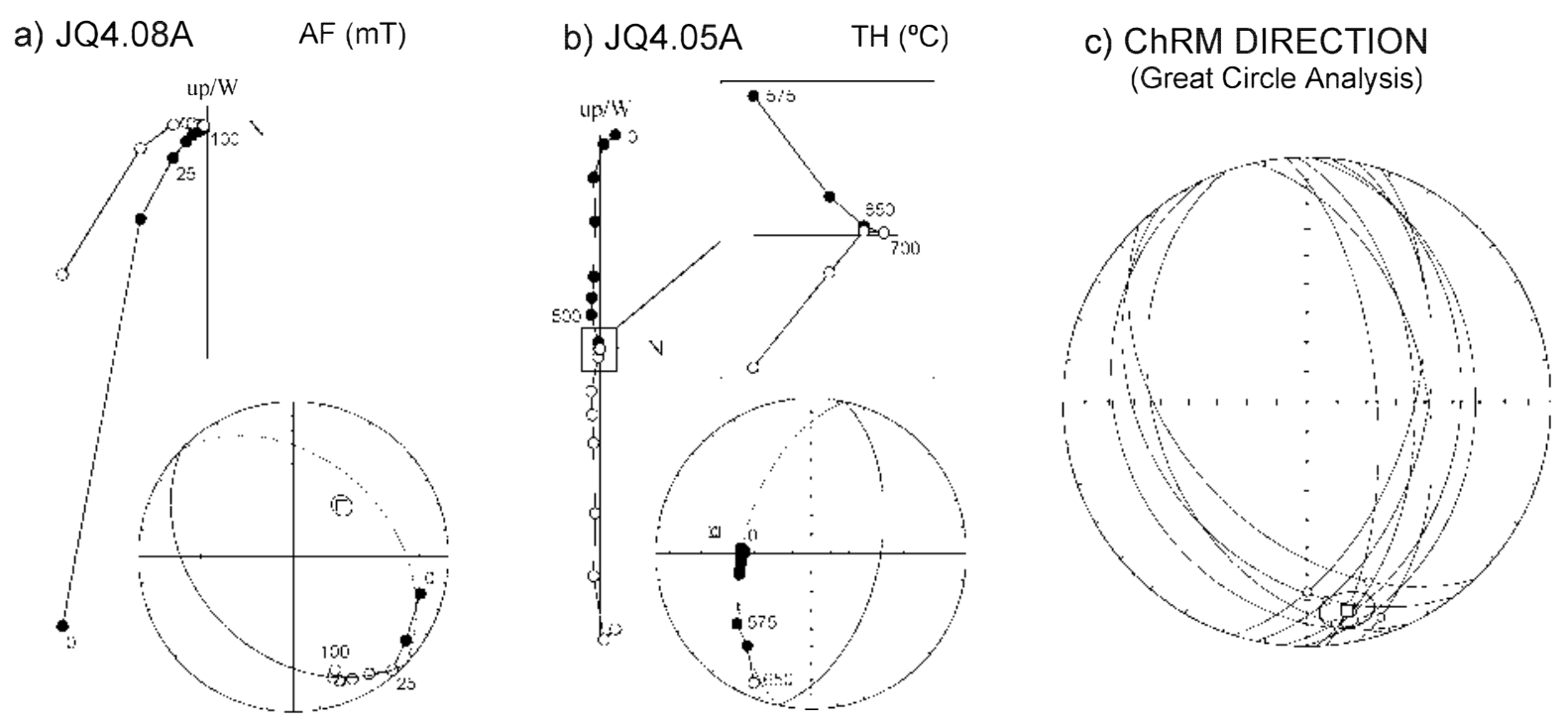

Fig. 4. Vector and equal-area projection plots during AF (a) and thermal (b) demagnetization of samples with two overlapping magnetic components. (c) Mean direction obtained with the great-circle analysis.

ary components were observed). Mora-Alvarez et al. (1991) considered that the NRM directions reflect two intermediate polarities (C8 and $\mathrm{C} 3-\mathrm{A}$ ) and one reversed direction of $\mathrm{Cl}$ (despite its high directional scatter).

Normal and reversed directions are antipodal (Fig. 5, Table 3). The mean direction is $D=348.4^{\circ}$, $I=32.4^{\circ}\left(N=28, k=17.3, \alpha_{95}=6.7^{\circ}\right)$. This mean direction has been obtained considering all data presented in this study, with the exception of the CM1 and MT sites due to the few available ChRM directions from these two sites. After inspection of Fig. $5 \mathrm{~b}$ and Table 3, there are three directional data (from CR2, MT2 and CR sites) that deviate more than 40 from the mean. These three sites (Fig. la and $\mathrm{b}$ ) are close to the transition zone between groups $\mathrm{B}$ and $\mathrm{C}$ of different polarities and could represent intermediate directions. These data have been eliminated from the mean direction calculated for tectonic purposes. The ChRM passes a reversal test of McFadden and McElhinny (1990) for a confidence level of $95 \% \quad\left(\gamma_{0}=9.29^{\circ}\right.$ and $\gamma_{\mathrm{c}}=10.51^{\circ}$ ). The classification obtained for the reversal test is $\mathrm{C}$. Therefore, the representative mean direction from Sierra de Las Cruces is $D=350.7^{\circ}$; $I=30.6^{\circ}\left(N=25, k=30.7\right.$ and $\left.\alpha_{95}=5.3^{\circ}\right)$. The mean Virtual Geomagnetic Pole (VGP) is: Plat $=161.8^{\circ}$;
Plon $=80.1^{\circ}\left(k=42.5 ; A_{95}=4.5, N=25 ; S=12.4^{\circ}\right)$. The $12.4^{\circ}$ dispersion of the site mean VGPs compares favorably with the $S \approx 13^{\circ}$ predicted for the paleolatitude of $\approx 20^{\circ}$ (Merril and McElhinny, 1983; Butler, 1992). This observation indicates that the dispersion of site mean VGPs is consistent with adequate sampling of geomagnetic secular variation. The mean direction is deviated to the west with respect to the expected direction assuming an axial dipolar geomagnetic field for the last $4 \mathrm{Ma}$. A further discussion on the significance of young tectonic rotations within the TMVB is given in Ruiz-Martínez et al (2000 - this volume).

Polarities of investigated sites, together with those of Mooser et al. (1974) and Mora-Alvarez et al. (1991), appear to have a magnetic zonation (Fig. 1b) in which a NNW-SSE profile shows six magnetozones from north to south. These comprise: $\mathrm{A}=$ normal polarity (sites $\mathrm{JQ1}, \mathrm{JQ2}$ and JQ3); $\mathrm{B}=$ reversed polarity (sites $\mathrm{JQ} 4, \mathrm{CM} 1$, IT, IT2, AJ1, AJ2, ST2, JI1 and ST3); $\mathrm{C}=$ normal polarity (sites CR, CR2, PL, MT, MT2, AY, ST4, ST5, ST1, PC2, $\mathrm{CH} 1, \mathrm{CH} 2, \mathrm{CH} 3$, and $\mathrm{GU} 3$ of this study; sites 3, 7 and 24 of Mooser et al., 1974; site C9 of Mora-Alvarez et al., 1991), D= reversed polarity (sites TO1 and TO3 of this study; sites 8 , 9, 11, 14, 27, 30, 16, 17 and 18 of Mooser et al., 
Table 3

Palaeomagnetic directions (this study)

\begin{tabular}{|c|c|c|c|c|c|c|c|c|}
\hline Site & Lat. $\left(19^{\circ} \mathrm{N}\right)$ & Long. $\left(99^{\circ} \mathrm{W}\right)$ & Polarity/magnetozone & Dec & Inc & $N$ & $k$ & $\alpha_{95}$ \\
\hline JQ1 & $34^{\prime} 10^{\prime \prime}$ & $35^{\prime} 28^{\prime \prime}$ & $\mathrm{N} / \mathrm{A}$ & 350.4 & 43.1 & 10 & 113.0 & 4.6 \\
\hline JQ2 & $33^{\prime} 48^{\prime \prime}$ & $34^{\prime} 50^{\prime \prime}$ & $\mathrm{N} / \mathrm{A}$ & 336.4 & 44.1 & 10 & 209.9 & 3.3 \\
\hline JQ3 & $33^{\prime} 48^{\prime \prime}$ & $34^{\prime} 40^{\prime \prime}$ & $\mathrm{N} / \mathrm{A}$ & 360.7 & 48.3 & 10 & 116.9 & 4.5 \\
\hline JQ4 & $33^{\prime} 32^{\prime \prime}$ & $33^{\prime} 38^{\prime \prime}$ & $\mathrm{R} / \mathrm{B}$ & 169.0 & -14.2 & 10 & G.C.A.: & $\operatorname{mad}=7.3$ \\
\hline $\mathrm{CMl}^{*}$ & $34^{\prime} 24^{\prime \prime}$ & $32^{\prime} 15^{\prime \prime}$ & $\mathrm{R} / \mathrm{B}$ & 155.8 & -21.6 & 3 & G.C.A.: & $\operatorname{mad}=2.6$ \\
\hline $\mathrm{AJ} 1$ & $32^{\prime} 00^{\prime \prime}$ & $29^{\prime} 49^{\prime \prime}$ & $\mathrm{R} / \mathrm{B}$ & 173.3 & -22.8 & 9 & 181.5 & 3.8 \\
\hline $\mathrm{AJ} 2$ & $31^{\prime} 20^{\prime \prime}$ & $28^{\prime} 05^{\prime \prime}$ & $\mathrm{R} / \mathrm{B}$ & 151.0 & -21.9 & 10 & 91.2 & 5.1 \\
\hline IT & $31^{\prime} 30^{\prime \prime}$ & $28^{\prime} 30^{\prime \prime}$ & $\mathrm{R} / \mathrm{B}$ & 171.3 & -20.9 & 10 & 258.2 & 3.0 \\
\hline IT2 & $31^{\prime} 30^{\prime \prime}$ & $28^{\prime} 30^{\prime \prime}$ & $\mathrm{R} / \mathrm{B}$ & 151.3 & -23.0 & 10 & 149.0 & 4.0 \\
\hline ST2 & $30^{\prime} 49^{\prime \prime}$ & $28^{\prime} 55^{\prime \prime}$ & $\mathrm{R} / \mathrm{B}$ & 145.3 & -34.6 & 5 & 121.4 & 7.0 \\
\hline JIl & $30^{\prime} 49^{\prime \prime}$ & $28^{\prime} 32^{\prime \prime}$ & $\mathrm{R} / \mathrm{B}$ & 176.5 & -22.3 & 7 & 312.2 & 3.4 \\
\hline ST3 & $30^{\prime} 00^{\prime \prime}$ & $28^{\prime} 34^{\prime \prime}$ & $\mathrm{R} / \mathrm{B}$ & 174.6 & -33.8 & 10 & 211.4 & 3.3 \\
\hline $\mathrm{CR}^{* *}$ & $31^{\prime} 18^{\prime \prime}$ & $27^{\prime} 00^{\prime \prime}$ & $\mathrm{N} / \mathrm{C}$ & 27.6 & 41.0 & 9 & 275.9 & 3.1 \\
\hline $\mathrm{CR} 2^{* *}$ & $31^{\prime} 23^{\prime \prime}$ & $26^{\prime} 49^{\prime \prime}$ & $\mathrm{N} / \mathrm{C}$ & 287.3 & 34.8 & 10 & 106.8 & 4.7 \\
\hline PL & $31^{\prime} 18^{\prime \prime}$ & $26^{\prime} 12^{\prime \prime}$ & $\mathrm{N} / \mathrm{C}$ & 12.3 & 23.5 & 10 & 225.6 & 3.2 \\
\hline $\mathrm{MT}^{*}$ & $31^{\prime} 18^{\prime \prime}$ & $24^{\prime} 39^{\prime \prime}$ & $\mathrm{N} / \mathrm{C}$ & 310 & 49 & 3 & - & - \\
\hline $\mathrm{MT}^{* *}$ & $31^{\prime} 10^{\prime \prime}$ & $25^{\prime} 28^{\prime \prime}$ & $\mathrm{N} / \mathrm{C}$ & 299.2 & 36.4 & 9 & 98.4 & 5.2 \\
\hline ST4 & $29^{\prime} 19^{\prime \prime}$ & $28^{\prime} 49^{\prime \prime}$ & $\mathrm{N} / \mathrm{C}$ & 349.1 & 33.1 & 10 & 57.8 & 6.4 \\
\hline ST5 & $28^{\prime} 07^{\prime \prime}$ & $29^{\prime} 00^{\prime \prime}$ & $\mathrm{N} / \mathrm{C}$ & 359.0 & 7.3 & 9 & 249.7 & 3.3 \\
\hline ST1 & $28^{\prime} 08^{\prime \prime}$ & $28^{\prime} 49^{\prime \prime}$ & $\mathrm{N} / \mathrm{C}$ & 332.3 & 33.1 & 10 & 156.8 & 3.9 \\
\hline AY & $29^{\prime} 40^{\prime \prime}$ & $22^{\prime} 00^{\prime \prime}$ & $\mathrm{N} / \mathrm{C}$ & 348.2 & 28.2 & 10 & 80.8 & 5.4 \\
\hline $\mathrm{CHl}$ & $26^{\prime} 15^{\prime \prime}$ & $19^{\prime} 20^{\prime \prime}$ & $\mathrm{N} / \mathrm{C}$ & 358.5 & 27.1 & 10 & 410.3 & 2.4 \\
\hline $\mathrm{CH} 2$ & $25^{\prime} 30^{\prime \prime}$ & $20^{\prime} 29^{\prime \prime}$ & $\mathrm{N} / \mathrm{C}$ & 355.2 & 32.2 & 10 & 51.6 & 6.8 \\
\hline $\mathrm{CH} 3$ & $26^{\prime} 15^{\prime \prime}$ & $21^{\prime} 18^{\prime \prime}$ & $\mathrm{N} / \mathrm{C}$ & 358.2 & 19.3 & 10 & 39.5 & 7.8 \\
\hline GU3 & $25^{\prime} 20^{\prime \prime}$ & $21^{\prime} 50^{\prime \prime}$ & $\mathrm{N} / \mathrm{C}$ & 357.2 & 36.2 & 10 & 115.3 & 4.5 \\
\hline PC2 & $25^{\prime} 20^{\prime \prime}$ & $25^{\prime} 53^{\prime \prime}$ & $\mathrm{N} / \mathrm{C}$ & 358.2 & 26.4 & 10 & 197.5 & 3.4 \\
\hline TO1 & $17^{\prime} 45^{\prime \prime}$ & $23^{\prime} 57^{\prime \prime}$ & $\mathrm{R} / \mathrm{D}$ & 167.3 & -26.7 & 10 & 130.5 & 4.2 \\
\hline TO3 & $19^{\prime} 00^{\prime \prime}$ & $19^{\prime} 31^{\prime \prime}$ & $\mathrm{R} / \mathrm{D}$ & 177.0 & -53.9 & 10 & 80.1 & 5.4 \\
\hline TO2 & $17^{\prime} 40^{\prime \prime}$ & $20^{\prime} 27^{\prime \prime}$ & $\mathrm{N}$ & 362.2 & 32.2 & 9 & 170.4 & 4.0 \\
\hline TO4 & $18^{\prime} 25^{\prime \prime}$ & $20^{\prime} 40^{\prime \prime}$ & $\mathrm{N}$ & 352.1 & 45.6 & 8 & 337.7 & 3.0 \\
\hline Mean direction (normal) & & & & 350.2 & 35.0 & 18 & 14.4 & 9.4 \\
\hline Mean direction (reverse) ${ }^{a}$ & & & & 165.4 & -27.8 & 10 & 28.9 & 9.1 \\
\hline Mean direction ${ }^{\mathrm{a}}$ & & & & 348.6 & 32.4 & 28 & 17.3 & 6.7 \\
\hline Mean direction (normal $)^{b}$ & & & & 354.4 & 32.4 & 15 & 35.2 & 6.5 \\
\hline Mean direction (reverse) ${ }^{b}$ & & & & 165.4 & -27.8 & 10 & 28.9 & 9.1 \\
\hline Mean direction ${ }^{\mathrm{b}}$ & & & & 350.7 & 30.6 & 25 & 30.7 & 5.3 \\
\hline Mean direction $(A+B)^{c}$ & & & & 345.3 & 30.4 & 11 & 28.0 & 8.8 \\
\hline Mean direction $(\mathrm{C}+\mathrm{D})^{\mathrm{d}}$ & & & & 354.6 & 29.2 & 12 & 34.8 & 7.5 \\
\hline
\end{tabular}

G.C.A.: great circle analysis. mad: maximum angular deviation.

${ }^{a}$ Computed without "sites.

${ }^{b}$ Excluding * and ${ }^{* *}$ sites.

${ }^{\circ}$ Mean directions for magnetozones A and B.

${ }^{\mathrm{a}}$ Mean direction for magnetozones $\mathrm{C}$ and D.

1974; site $\mathrm{C} 1$ of Mora-Alvarez et al., 1991); $\mathrm{E}=$ normal polarity? (this magnetozone is defined only with two sites of Mooser et al., 1974: 10 and 13), and $\mathrm{F}=$ normal polarity (sites 20, 28 and $\mathrm{C} 3$ ).

\section{Geochronological study}

In order to determine the age of the magnetozones defined by the palaeomagnetic study, $\mathrm{K}-$ 

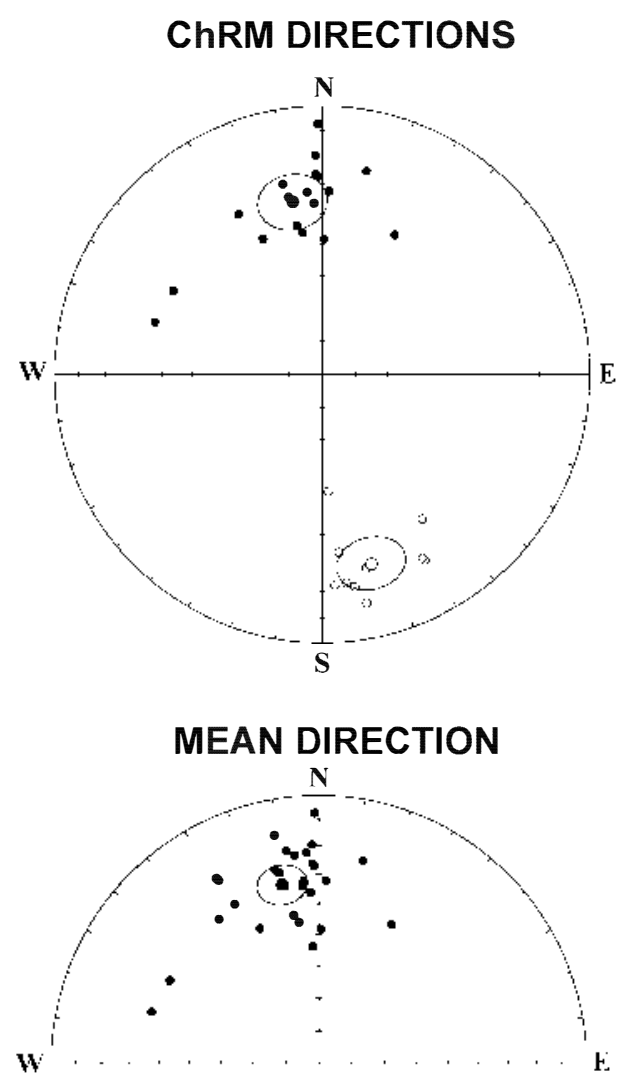

Fig. 5. Equal-area projections showing normal and reversed directions (a) and mean directions (b) for the investigated sites (with the exception of CM1 and MT sites).

Ar radiometric studies were made on sites JQ2, $\mathrm{CH} 1, \mathrm{ST} 1$ and $\mathrm{TO} 2$ at the Laboratorio de Geocronología y Geoquímica Isotópica of the Complutense University of Madrid, using wholerock samples of the three rock types (Table 1). A brief petrographic description of investigated sites is given in Table 4 . The potassium contents were determined in duplicate using an Eppendorf ${ }^{\mathbb{C}}$ flame photometer with sodium buffered solutions, and the argon analyses were by isotope dilution using a VG Micromass $603^{\circ}$ mass spectrometer. The errors are quoted throughout as two standard deviations. The ${ }^{40} \mathrm{~K}$ constants used were those recommended by Steiger and Jäger (1977): $\lambda_{\mathrm{b}}=4.962 \times 10^{-10} \mathrm{a}^{-1}, \lambda_{\mathrm{a}}=0.581 \times 10^{-10} \mathrm{a}^{-1}$ and ${ }^{40} \mathrm{~K}_{\text {total }}=1.17 \times 10^{-2}$ at.\%. In addition, a $\mathrm{K}-\mathrm{Ar}$ radiometric study on plagioclase concentrate from site $\mathrm{AJ} 2$ was performed at the Geochron
Table 4

Petrographic description of the K-Ar-dated sites

\begin{tabular}{|c|c|}
\hline Site & Description \\
\hline JQ2 & $\begin{array}{l}\text { Clinopyroxene-amphibol-plagioclase andesite } \\
\text { flow. Partially oxidized amphibole in a ground- } \\
\text { mass of augite, plagioclase, hypersthene and } \\
\text { opaques }\end{array}$ \\
\hline $\mathrm{AJ} 2$ & $\begin{array}{l}\text { Andesite flow with phenocryst of plagioclase } \\
\text { (andesine) partially oxidized hornblende and } \\
\text { minor amounts of quartz in a groundmass of } \\
\text { plagioclase, augite and opaques }\end{array}$ \\
\hline $\mathrm{CH} 1$ & $\begin{array}{l}\text { Basalt flow with scarce phenocrysts of olivine, } \\
\text { augite and plagioclase. Microcrystalline ground- } \\
\text { mass with plagioclase, augite and opaques }\end{array}$ \\
\hline ST1 & $\begin{array}{l}\text { Dacite } \text { tufl": with quartz, hornblende, augite and } \\
\text { plagioclase phenocrysts. Some plagioclase xen- } \\
\text { ocrysts. The groundmass has the same composi- } \\
\text { tion than JQ2 }\end{array}$ \\
\hline TO2 & $\begin{array}{l}\text { Augite-hornblende-plagioclase basalt flow. } \\
\text { Abundant phenocrysts of augite and strongly } \\
\text { oxidized hornblende in a groundmass of plagio- } \\
\text { clase, augite and opaques }\end{array}$ \\
\hline
\end{tabular}

Laboratory, Krueger Enterprises. These radiometric data indicate that the Las Cruces eruptive period extended continu.ously from $3.71 \pm 0.40$ to $1.79 \pm 0.10 \mathrm{Ma}$, with the oldest ages occurring in the north and the youngest in the south.

\section{Discussion and conclusions}

The magnetostratigraphic zonation is consistent with that indicated by the radiometric determinations. If the geomagnetic polarity time scale, as revised by Cande and Kent (1995), is used, then it is possible to compare the predicted radiometric ages with those actually measured. Magnetozone A corresponds to Polarity Chron C2An.3n (Gauss) between 3.330-3.580 Ma. Magnetozone B can be ascribed to C2An.1r (the Kaena event), C2An.2r (the Mammoth event) or to the upper part of the C2r.2r Chron (the Gilbert chron). It is considered that it most likely corresponds with the Kaena and/or the Mammoth event (C2An.1r or 2r Subchrons). Magnetozone $\mathrm{C}$ contains three radiometric determinations, but the error bars mean that the STl site, in a magnetozone of normal polarity, could be either $\mathrm{C} 2 \mathrm{n}, \mathrm{C} 2 \mathrm{r} .1 \mathrm{n}$ or 
C2An.1n, while the $\mathrm{C} 11$ and C9 sites of MoraAlvarez et al. (1991), also of normal polarity, probably belong to $2 \mathrm{An}$. $\mathrm{ln}$ Chron, but taking into account the $2 \sigma$ error, they could also belong to $2 \mathrm{An} .2 \mathrm{n}$ Chron. If all the volcanic episodes correspond to the same magnetic chron, then the most likely is the 2An.1n Chron (Gauss). Magnetozone $\mathrm{D}$ is of reversed polarity. The radiometric data $\mathrm{C} 1$ from Mora-Alvarez et al. (1991) suggest correspondence with either C2r.1r or C2r.2r Chrons (Matuyama). Magnetozone $\mathrm{E}$ is a small region of normal polarity that is only defined by palaeomagnetic data from Mooser et al. (1974). As discussed earlier, the lack of adequate demagnetization may raise doubts about the polarity of their samples. However, the only radiometric data from this region is that of the $\mathrm{C} 8$ site of Mora-Alvarez et al. (1991) (Table 1), which is of an intermediate direction and could be ascribed to the $\mathrm{C} 2 \mathrm{r}-\mathrm{C} 2 \mathrm{n}$ transition (Matuyama-Olduvai-Matuyama). Therefore, with the available data, this magnetozone, if it exists, could be related to the $\mathrm{C} 2 \mathrm{n}$ Subchron (Olduvai). Magnetozone F corresponds to the Cln Chron (Brunhes).

Combining the magnetostratigraphic and radiometric data, the volcanic activity of Las Cruces eruptive period can be best constrained between 3.6 and $1.8 \mathrm{Ma}$, and a southeastern migration of the volcanic activity is clearly documented. The good agreement between magnetostratigraphic and radiometric data, and the consistent magnetic zonation pattern that seems to be approximately perpendicular to the trend of the range (NNW-SSE), enable an estimate to be made of the apparent mean rate of migration along a NNW-SSE profile. Fig. 6a shows the relationship between the location of the Pliocene sites (projected along the $\mathrm{P}-\mathrm{P}^{\prime}$ direction, Fig. $1 \mathrm{~b}$ ) and the radiometric ages. The mean southeastward migration rate estimated from radiometric data for Las Cruces Formation [i.e. with the exception of TO2, this study, and C3 (Mora-Alvarez et al., 1991), that correspond to other eruptive events different to Las Cruces] is about $1.6 \mathrm{~cm} / \mathrm{a}$. Fig. $6 \mathrm{~b}$ illustrates the magnetostratigraphic correlation between the geomagnetic polarity time scale of Cande and Kent (1995) and the interpretation of the spatial magnetic zonation given above. According to this magnetostratigraphic correlation, two different slopes can be observed, which represent different migration rates. From the oldest volcanism (Gauss magnetozone), a mean rate of southeastern migration of about $4.1 \mathrm{~cm} / \mathrm{a}$ has been calculated. A slower rate, about $0.95 \mathrm{~cm} / \mathrm{a}$, is obtained for the younger volcanism represented by the BrunhesMatuyama magnetozones. Although the magnetostratigraphic correlation carried out in this study represents an implicit idealization of the migration phenomenon and volcano-stratigraphic studies are necessary in the northern sector of Sierra de Las Cruces to test the magnetic zonation proposed, the present palaeomagnetic and radiometric results seem to be mutually consistent with this model.

The modern volcanic arc in the Mexico basin, as defined by the major andesitic centers, is located towards the south and east of the Sierra de Las Cruces (Chichinautzin Group, Sierra Río Frío and Sierra Nevada). On the basis of radiometric, palaeomagnetic and volcano-stratigraphic studies, Nixon et al. (1987) concluded that the volcanic activity since $1.7 \mathrm{Ma}$ has become focused at the volcanic front, where the Popocatepelt volcano is located. Therefore, the southern migration of the volcanism in this region has been active, at least, since the late Pliocene up to the present. However, with the available data from these regions, it is not yet possible to estimate migration rates from 1.7-1.9 Ma up to the present.

Documented volcanic migrations in the Michoacan-Guanajuato volcanic field (Ban et al., 1992) and in the Chapala area (Delgado-Granados et al., 1995) seems to present a SSW orientation. Delgado-Granados et al. (1995) consider that the volcanic migration is consistent with the distance and relative orientation to the Middle America Trench. In contrast, the observed migration in the Sierra de Las Cruces presents a SSE trend. Other reported migrations of the volcanic activity in the eastern part of the TMVB are not so well documented but seem to follow a SSE trend (Cantagrel and Robin, 1979). This observed different pattern between the Michoacan and Chapala areas from an eastern region, which would extend from the Queretaro-Taxco lineament towards the Gulf of Mexico, demonstrates the importance of this tectonic signature. Pasquarè et al. $(1986,1991)$ and 


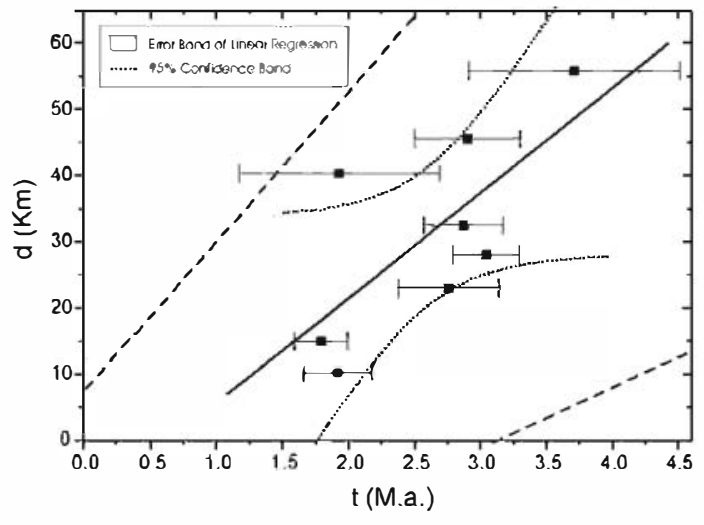

a) Radiometric data $( \pm 2 \sigma)$

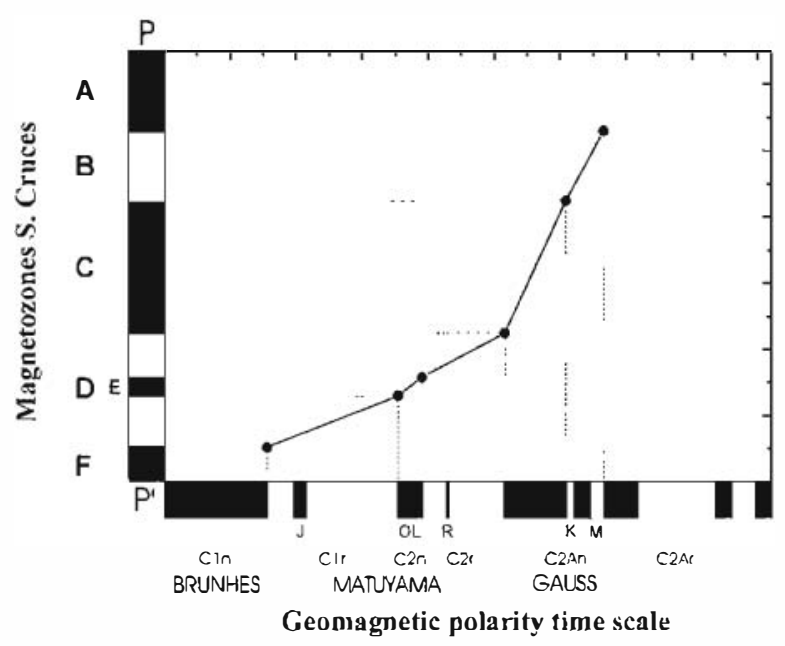

b) Magnetostratigraphic correlation

Fig. 6. (a) Ages of investigated sites plotted against its location projected in the direction of the NNW-SSE trend of Sierra de Las Cruces range $\left(\mathrm{P}-\mathrm{P}^{\prime}\right)$. Data are taken from Table 1. Vertical bars represent standard deviation of radiometric data. (b) Magnetostratigraphic correlation between Sierra de Las Cruces magnetozones and the geomagnetic polarity time scale (Cande and Kent, 1995).

Soler-Arechalde and Urrutia-Fucugauchi (1995) proposed that the Queretaro-Taxco lineament was a major structural boundary, which was mostly reactivated during Pliocene times, between the central and eastern segments of the TMVB. The Chapala area and the Michoacan-Guanajuato volcanic field are to the west of the Queretaro fault system and are characterized by E-W-oriented normal faults and small grabens. Towards the east, small NW-SE basins and ridges delineate a zone with widespread volcanism without any clear large E-W lineaments. In addition, Nixon et al. (1987) point out that the modern volcanic arc, in its western part, began to evolve between 0.6 and $0.2 \mathrm{Ma}$. In contrast, in the eastern segment, the construction of the andesite-dacite cones started considerably earlier, at approximately $1.7 \mathrm{Ma}$.

Regarding the rate of the migration, in the Michoacan-Guanajuato volcanic field, Ban et al. (1992) concluded that the volcanic activity shifted about $100 \mathrm{~km}$ southward during the last $1-2 \mathrm{Ma}$, but as an abrupt jump, rather than a gradual progression. From their data, an estimated mean rate of about $2 \mathrm{~cm} / \mathrm{a}$ of apparent migration has been calculated along the SSE direction from 2.35 to $0.7 \mathrm{Ma}$ (i.e. prior to the modern volcanic arc).
This migration rate increases towards the youngest volcanism. In the Chapala area, the migration rates could not be estimated from the few PliocenePleistocene data presented by Delgado-Granados et al. (1995). The authors concluded that in the Chapala region, a transitional and smaller spatial migration occurred around the PliocenePleistocene boundary.

Nixon et al. (1987) considered that the cause of the trenchward migration of arc volcanism, which was completed by the Early Quaternary, could be related by plate readjustments at $3.5 \mathrm{Ma}$ or earlier (Mammerickx and Klitgord, 1982). However, they argued that the gradual focusing of the andesitic volcanism towards the volcanic front in the Quaternary cannot be related to documented plate reorganizations and occurred much too rapidly to represent a direct response to a significant change in dip of the subducted slab. Ban et al. (1992) and Delgado-Granados et al. (1995) suggest that the trenchward migration of volcanism could be related to a steepening of the subduction angle of the Cocos plate. In addition, they consider that a shift seaward of the position of the trench could also have originated the southward migration. The order of magnitude of the 
reported southward migration of volcanic activity in both regions prior to the development of the modern magmatic arc seems to indicate that the mechanism responsible for this phenomenon is related to plate tectonic readjustments. However, the differences in the orientation of the volcanic drift stress the role of the orientation of the crustal fault zones that provided suitable magma paths from the source region to the surface.

The mean direction calculated in the previous section $\left(D=350.7^{\circ} ; I=30.6^{\circ}, N=25, k=30.7\right.$ and $\alpha_{95}=5.3^{\circ}$ ) represents a mean of the $3.6-0.7 \mathrm{Ma}$ time span. This direction could reflect a small counterclockwise rotation. A mean direction has also been computed from the older and younger magnetozones (Table 3). Magnetozones A and B give a mean direction of $D=345.3^{\circ}, I=30.4^{\circ}(N=$ $11, k=28.0, \alpha_{95}=8.8^{\circ}$ ), and for the magnetozones $\mathrm{C}$ and $\mathrm{D}$, the mean direction is $D=354.6^{\circ}, I=$ $29.2^{\circ} \quad\left(N=12, \quad k=34.8, \quad \alpha_{95}=7.5^{\circ}\right) . \quad$ Although, strictly speaking, both directions are statistically undifferentiated and it is not certain that the secular variation has been averaged, a difference in declination of about $9^{\circ}$ between both directions is observed that is not shown in inclination values. This suggests that a small counterclockwise rotational component may be coeval with the southeastern migration of the Sierra de Las Cruces. However, this should be considered only as a speculative hypothesis and must be tested in other regions in the eastern TMVB.

\section{Acknowledgements}

Most of the $\mathrm{K}-\mathrm{Ar}$ analyses were carried out at the CAI: Laboratorio de Geocronología $y$ Geoquímica Isotópica of the Complutense University. We are very grateful for the facilities and the service that this Institution has provided. We thank Juan Nuñez-Aguilar and Cristina Osete for their help with the drawings. The field work was completed during a stay of three months by one of the authors (M.L.O.) at the Instituto de Geofísica of UNAM, Mexico, which was funded by Intercambio Academico (UNAM). M.L.O. also very much appreciates the help of Martín Espinosa and Teodoro Hernandez and is indebted to Ana María Soler and her family and to Dante Morán for their friendly support. Avto Gogichaishvili and two anonymous reviewers provided useful comments that have improved the manuscript. The project was supported by the European Union (project: CI-CT94-0114).

\section{References}

Ban, M., Hasenaka, T., Delgado-Granados, H., Takaoka, N., 1992. K-Ar ages of lavas from shield volcanoes in the Michoacan-Guanajuato volcanic field, Mexico. Geofis. Int. 31, 467-475.

Butler, R.F., 1992. Paleomagnetism: Magnetic Domains to Geological Terranes. Blackwell Scientific Publications, Boston, MA. 319 pp.

Cande, S.C., Kent, D.V., 1995. Revised calibration of the geomagnetic polarity timescale for the Late Cretaceous and Cenozoic. J. Geophys. Res. 100, B46093-B46095.

Cantagrel, J.M., Robin, C., 1979. K-Ar dating on Eastern Mexican volcanic rocks - Relations between the andesitic and the alkaline Provinces. J. Volcanol. Geotherm. Res. 5, 99-114.

Delgado-Granados, H., Martín del Pozo, A.L., 1993. Pliocene to Holocene volcanic geology at the junction of Las Cruces Chichinautzin and Ajusco ranges, southwest of Mexico City. Geofis. Int. 32 (3), 511-522.

Delgado-Granados, H., Urrutia-Fucugacuhi, J., Hasenaka, T., Ban, M., 1995. Southwestward volcanic migration in the western Trans-Mexican Volcanic Belt during the last $2 \mathrm{Ma}$. Geofis. Int. 34 (3), 341-352.

Demant, A., 1978. Características del Eje Neovolcánico Transmexicano y sus problemas de interpretación. Revista Inst. Geol. U.N.A.M. 2, 172-187.

Ferrari, L., Garduño, V.H., Pasquarè, G., Tibaldi, A., 1994. Volcanic and tectonic evolution of central México: Oligocene to present. Geofis. Int. 33 (1), 91-105.

Ferrari, L., Vaggelli, G., Petrone, C.M., Manetti, P., Conticelli, S., 2000. Late Miocene volcanism and intra-arc tectonics during the early development of the Trans-Mexican volcanic belt. Tectonophysics 318, 161-185.

Fries, C., 1960. Geología del Estado de Morelos y partes adyacentes de México y Guerrero, región central meridional de México. U.N.A.M. Inst. Geol. Bol. 60, 236.

Gunn, B.M., Mooser, F., 1971. Geochemistry of the volcanics of central México. Bull. Volcanol. 34, 577-616.

Halls, H.C., 1976. A least-squares method to find a remanence direction from converging remagnetization circles. Geophys. J. R. Astron. Soc. 45, 297-304.

INEGI, 1986. Carta geológica E14-2. Dirección General de Geografía. Secretaría de Programación y Presupuesto, Mexico.

Kirschvink, J.L., 1980. The least-squares line and plane and the 
analysis of paleomagnetic data. Geophys. J. R. Astron. Soc. $62,699-718$.

Lugo-Hubp, J., 1984. Geomorfología del sur de la cuenca de México. Inst. Geografía, UNAM, Serie Varia 1 (9), 95 pp.

Luhr, J.F., Nelson, S.A., Allan, J.F., Carmichael, I.S.E., 1985 Active rifting in southwestern Mexico: Manifestations of an incipient eastward spreading-ridge jump. Geology 13, 54-57.

McFadden, P.L., McElhinny, M.W., 1988. The combined analysis of remagnetization circles and direct observations in palaeomagnetism. Earth Planet. Sci. Lett. 87, 161-172.

McFadden, P.L., McElhinny, M.W., 1990. Classification of the reversal test in paleomagnetism. Geophys. J. Int. 103, $725-729$.

Mammerickx, J., Klitgord, K., 1982. Northern East Pacific Rise: Evolution from 25 m.y. B.P. to the present. J. Geophys. Res. 87, 6751-6759.

Merril, R.T., McElhinny, M.W., 1983. The Earth's Magnetic field: Its History Origin and Planetary Perspective. Academic Press, London. 401 pp.

Molnar, P., Sykes, L., 1969. Tectonics of the Caribbean and Middle American regions from focal mechanisms and seismicity. Geol. Soc. Am. Bull. 80, 1639-1684.

Moore, G., Marone, C., Carmichael, I.S.E., Renne, P., 1994. Basaltic volcanism and extension near the intersection of the Sierra Madre volcanic province and the Mexican volcanic belt. Geol. Soc. Am. Bull. 106, 383-394.

Mooser, F., 1972. The Mexican volcanic belt: Structure and tectonics. Geofis. Int. 12, 55-70.

Mooser, F., Nairn, A.E.M., Negendank, J.F.W., 1974. Palaeomagnetic investigations of the Tertiary and Quaternary igneous rocks: VIII A Palaeomagnetic and petrologic study of volcanics of Valley of Mexico. Geol. Rundsch. 63, 451-483.

Mora-Alvarez, G., Caballero, C., Urrutia-Fucugauchi, J., Uchiumi, S., 1991. Southward migration of volcanic activity in the Sierra de Las Cruces, basin of Mexico? A preliminary $\mathrm{K}-\mathrm{Ar}$ dating and palaeomagnetic study. Geofis. Int. 30 (2), 61-70.

Nixon, G.T., 1982. The relationship between Quaternary volcanism in central Mexico and the seismicity and the structure of subducted oceanic lithosphere. Geol. Soc. Am. Bull. 93, 514-523.

Nixon, G.T., Demant, A., Amstrong, R.L., Harakal, J.E., 1987. $\mathrm{K}-\mathrm{Ar}$ and geologic data bearing on the age and evolution of the Trans-Mexican Volcanic Belt. Geofis. Int. 26 (1), 109-158

Ozdemir, O., 1990. High-temperature hysteresis and thermoremanence of single-domain maghemite. Phys. Earth Planet. Inter. $65,125-136$.

Pardo, M., Suarez, G., 1995. Shape of the subducted Rivera and Cocos plates in southern México: Seismic and tectonic implications. J. Geophys. Res. B, 100 (7), 12357-12373.

Pasquarè, G., Forcella, F., Tibaldi, A., Vezzoli, L., Zanchi, A., 1986. Structural behaviour of a continental volcanic arc. In: Wezel, C. (Ed.), The Mexican Volcanic Belt. The Origin of Arcs. Elsevier, Amsterdam, pp. 509-527.

Pasquarè, G., Ferrari, L., Garduño, V.H., Tibaldi, A., Vezzoli, L., 1991. In: Geology of the Central Sector of the Mexican Volcanic Belt States of Guanajuato and Michoacán. Geol. Soc. Am. Map and Chart Series MCH072, 22 pp.

Richter, R., Negendank, J.F.W., 1976. Spurenelementuntersuchungen an Vulkaniten des Tales von Mexiko. Muenster. Forsch. Geol. Palaeontol. 38-39, 179-200.

Rosas-Elguera, J., Ferrari, L., López-Martínez, M., UrrutiaFucugauchi, J., 1997. Stratigraphy and tectonics of the Guadalajara region and the triple-junction area western Mexico. Int. Geol. Rev. 39, 125-140.

Ruiz-Martínez, V.C., Osete, M.L., Vegas, R., Nüñez-Aguilar, J.I., Urrutia-Fucugauchi, J., Tarling, D.H., 2000. Palaeomagnetism of Late Miocene to Quaternary rocks from the Eastern Segment of the Trans-Mexican Volcanic Belt. Tectonophysics 318, 217-233.

Soler-Arechalde, A.M., Urrutia-Fucugauchi, J., 1995. Evidencias de geosutura en el centro de Mexico. Bol. Geos. 15, 71.

Schlaepfer, C., 1968. Hoja México 14Q-h(5), con resumen de la Hoja México, Distrito Federal y Estados de México y Morelos, Carta Geol. de Méx., serie 1:100.000. U.N.A.M. Inst. Geol.

Shurbet, D.H., Cebull, S.E., 1973. Tectonic interpretation of the Trans-Mexican volcanic belt. Tectonophysics 101, $159-165$

Steiger, R.H., Jäger, E., 1977. Subcommission of geochronology: Convention on the use of decay constants in geochronology and cosmochronology. Earth Planet. Sci. Lett. 36, 359-362.

Urrutia-Fucugauchi, J., Böhnel, H., 1988. Tectonics along the Trans-Mexican volcanic belt according to palaeomagnetic data. Phys. Earth Planet. Inter. 52, 320-329.

Urrutia-Fucugauchi, J., Del Castillo, L., 1997. Un modelo del eje neovolcánico mexicano. Bol. Soc. Geol. Mex. 38, 18-26. 